\title{
СТЕРИЧЕСКИЙ КОНТРОЛЬ СИНТЕЗА ДИАЦЕТОКСИПРОИЗВОДНЫХ 1-ФЕНИЛ-1(2)-ОКТЕНОВ
}

\author{
А.В.де Векки, 3.М. Саркисян \\ Кафедра общей и медицинской химии им. профессора В.В. Хорунжего, \\ Санкт-Петербургский государственный педиатрический медицинский университет, \\ 194100, Россия, Санкт-Петербург, ул. Литовская, д. 2.
}

DOI: 10.19163/MedChemRussia2021-2021-412

E-mail: gertsog5000@yandex.ru

Совместное проведение реакций окислительного кросс-сочетания и ацетоксилирования позволяет получать функционализированные объекты, часть из которых является синтонами супрамолекулярных структур, способных выступать молекулярными переключателями, а также дендримерных структур, возможности использования которых в прицельной транспортировке лекарственных препаратов и OLED-технологиях трудно переоценить.

Нами показано, что при окислительном кросс-сочетании стирола и 1-гексена в присутствии интерметаллического катализатора $\mathrm{Pd}_{3} \mathrm{Sb}$ образуется окта-1,3диенилбензол, который в среде ледяной уксусной кислоты и $\mathrm{RhBi}_{4}$ ацетоксилируется согласно уравнению<smiles>[123I]C=CC=Cc1ccccc1</smiles><smiles>O=C(O)C(=O)O</smiles><smiles>[I-]c1ccccc1</smiles><smiles>c1ccccc1</smiles><smiles>CC(=O)O</smiles><smiles>C1CCCCC1</smiles><smiles>CCC(C(C)=O)C(/C=C/c1ccccc1)OC(C)=O</smiles><smiles>CCCCCC(/C=C/C(OC(C)=O)c1ccccc1)OC(C)=O</smiles>

Установлено, что при температуре $100{ }^{\circ} \mathrm{C}$ в присутствии кислорода и указанных катализаторов происходит позиционная и геометрическая изомеризация 1,2-, 3,4- и 1,4-диацетоксипроизводных 1-фенил-1(2)-октенов. Введение в композицию $\mathrm{Pd}_{3} \mathrm{Sb}-\mathrm{RhBi}_{4} / \mathrm{C}$ до 10 ат. \% $\operatorname{Ir}_{2} \mathrm{O}_{3}$ приводит к увеличению регио- и стереоселективности реакции диацетоксилирования за счет нивелирования направления, ответственного за образование изомеров 1,4-присоединения и перераспределения E- и Z-изомеров с доминантой последних, и процесс становится кинетически контролируемым. Полученный результат является принципиальным для синтеза некоторых современных фармацевтических препаратов, призванных бороться со СПИД или злокачественными новообразованиями.

\section{Литература}

[1] de Vekki A., Grisha A. Cross-coupling under conditions of acetoxylation reaction. Intermetallic Catalysis. - Saarbrücken, Deutschland: Palmarium Acad. Publish. 2014. 92 S.

[2] Гриша А.С., де Векки А.В.// Ж. прикл. химии. 2011. Т. 84, вып. 9. С. 1510-1516. 